\title{
A prepontine subarachnoid abscess by Escherichia coli
}
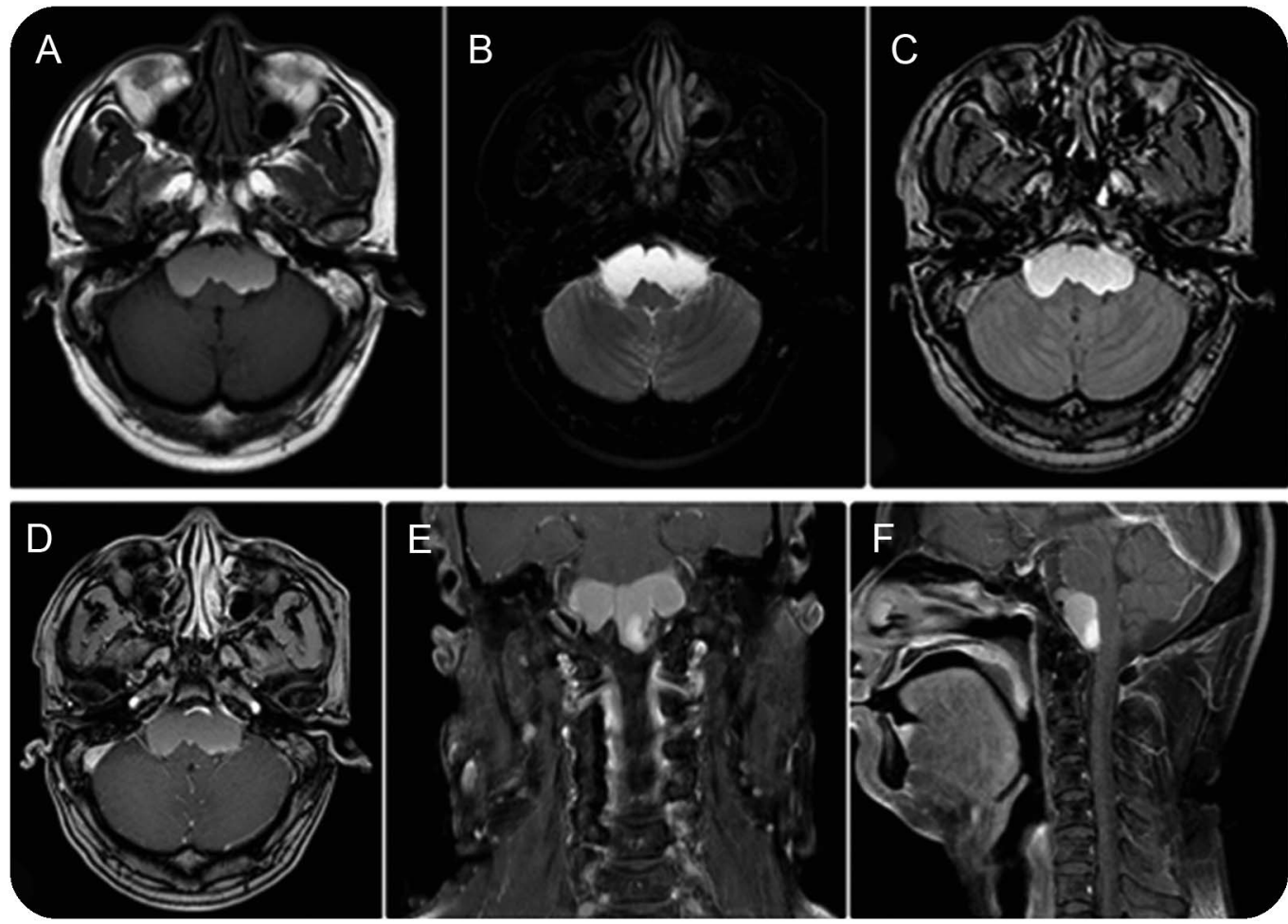

MRI showed the cystic mass in the prepontine region, characterized by homogeneous hyperintensity in T1-weighted (A), T2weighted $(B)$, and fluid-attenuated inversion recovery $(C)$ images. Axial $(D)$, coronal $(E)$, and sagittal $(F)$ postgadolinium T1weighted sequence did not suggest definitive enhancement, but showed a nodular hyperintensity inside.

A 53-year-old man had 6 months of intermittent fever and worsening headache, with $4 / 5$ left hemiparesis and new unsteady gait, without other deficits. His immune status was normal, and he had self-treated with paracetamol-caffeine-aspirin powder. Two years prior he had purulent meningitis diagnosed by lumbar puncture with negative CSF culture, treated with ceftriaxone/vancomycin for 2 weeks.

Radiologic examination demonstrated a prepontine cystic mass (figure 1). Intraoperatively, the mass was purulent (figure 2); a few foam cells were seen on biopsy. Culture of fluid from the cyst revealed Escherichia coli. Recovery occurred after a 4-week course of meropenem.

$E$ coli intracranial abscesses or subdural empyemas are infrequently reported. ${ }^{1,2}$ In our immunocompetent patient, a spontaneous prepontine subarachnoid $E$ coli abscess was unanticipated.

Yanming Ren, MD, * Chao You, PhD, ${ }^{*}$ Xuesong Liu, MD

*These authors contributed equally to this work as co-first authors.

From West China Hospital of Sichuan University, Chengdu, China.

Author contributions: All authors were involved in clinical care and investigative workup of the patient. Yanming Ren and Chao You drafted the manuscript. Xuesong Liu critically revised the manuscript.

Acknowledgement: The staff (Department of Neurosurgery, West China Hospital) performed the surgery and clinical care of the patient. Study funding: No targeted funding reported. 

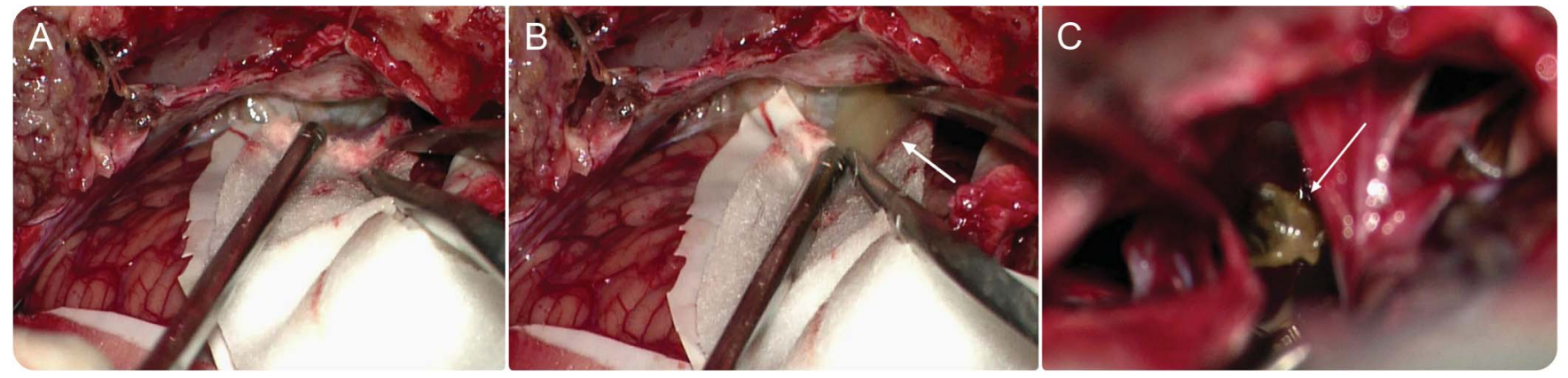

(A, B) The cystic mass had an intact capsule with purulent fluid inside (arrow). (C) Yellow matter (arrow) was observed and biopsy showed foam cells (not shown).

Disclosure: The authors report no disclosures relevant to the manuscript. Go to Neurology.org for full disclosures.

Correspondence to Dr. Liu: xuesongliu98@gmail.com

1. Rojas-Medina LM, Esteban-Fernandez L, Gutierrez-Cierco JA, Rodriguez-Berrocal V. Spontaneous subdural empyema by Escherichia coli: case report and literature review. Enferm Infecc Microbiol Clin 2016;34:531-532.

2. Akuzawa N, Osawa T, Totsuka M, et al. Secondary brain abscess following simple renal cyst infection: a case report. BMC Neurol 2014;14:130.

\section{WriteClick ${ }^{\circledR}$ rapid online correspondence}

Have a comment on a recent Neurology ${ }^{\circledR}$ article you would like to share? Now it is easier and more convenient. Neurology.org has launched WriteClick on the home page and sidebars of each article to encourage remarks and debate among users.

WriteClick is restricted to comments about studies published in Neurology within the last eight weeks.

Learn more at Neurology.org/letters

\section{Share Your Artistic Expressions in Neurology 'Visions'}

AAN members are urged to submit medically or scientifically related artistic images, such as photographs, photomicrographs, and paintings, to the "Visions" section of Neurology ${ }^{\circledR}$. These images are creative in nature, rather than the medically instructive images published in the NeuroImages section. The image or series of up to six images may be black and white or color and must fit into one published journal page. Accompanying description should be 100 words or less; the title should be a maximum of 96 characters including spaces and punctuation.

Learn more at www.aan.com/view/Visions, or upload a Visions submission at submit.neurology.org. 


\section{Neurology}

\section{A prepontine subarachnoid abscess by Escherichia coli \\ Yanming Ren, Chao You and Xuesong Liu \\ Neurology 2017;88;2335-2336 \\ DOI 10.1212/WNL.0000000000004040}

This information is current as of June 12, 2017

\begin{tabular}{|c|c|}
\hline $\begin{array}{l}\text { Updated Information \& } \\
\text { Services }\end{array}$ & $\begin{array}{l}\text { including high resolution figures, can be found at: } \\
\text { http://n.neurology.org/content/88/24/2335.full }\end{array}$ \\
\hline References & $\begin{array}{l}\text { This article cites } 2 \text { articles, } 0 \text { of which you can access for free at: } \\
\text { http://n.neurology.org/content/88/24/2335. full\#ref-list- } 1\end{array}$ \\
\hline Subspecialty Collections & $\begin{array}{l}\text { This article, along with others on similar topics, appears in the } \\
\text { following collection(s): } \\
\text { Abscess } \\
\text { http://n.neurology.org/cgi/collection/abscess } \\
\text { Bacterial infections } \\
\text { http://n.neurology.org/cgi/collection/bacterial_infections } \\
\text { Meningitis } \\
\text { http://n.neurology.org/cgi/collection/meningitis }\end{array}$ \\
\hline Permissions \& Licensing & $\begin{array}{l}\text { Information about reproducing this article in parts (figures,tables) or in } \\
\text { its entirety can be found online at: } \\
\text { http://www.neurology.org/about/about_the_journal\#permissions }\end{array}$ \\
\hline Reprints & $\begin{array}{l}\text { Information about ordering reprints can be found online: } \\
\text { http://n.neurology.org/subscribers/advertise }\end{array}$ \\
\hline
\end{tabular}

Neurology ${ }^{\circledR}$ is the official journal of the American Academy of Neurology. Published continuously since 1951, it is now a weekly with 48 issues per year. Copyright (O 2017 American Academy of Neurology. All rights reserved. Print ISSN: 0028-3878. Online ISSN: 1526-632X.

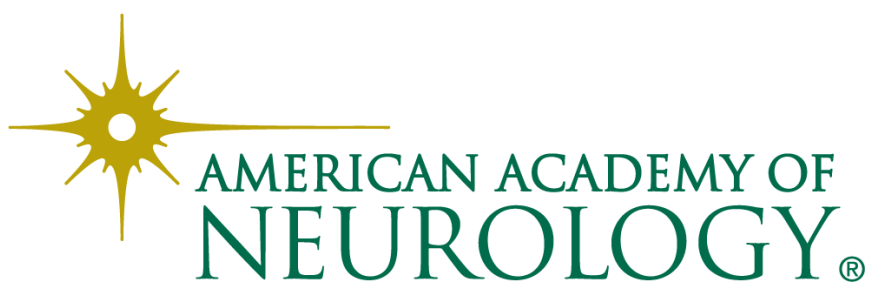

